DOI: 10.35340/2308-104X.2020.86-1-13

\section{СТРАТЕГІЧНЕ ПЛАНУВАННЯ ЯК МЕХАНІЗМ ДЕРЖАВНОГО УПРАВЛІННЯ ОСВІТОЮ}

\section{STRATEGIC PLANNING AS A MECHANISM OF PUBLIC MANAGEMENT OF EDUCATION}

\author{
ХИТЬКО М. М., \\ кандидат наук 3 державного \\ управління, доцент кафедри \\ публічного управління та права, \\ Дніпровська академія неперервної \\ освіти
}

\author{
HITKO M., \\ PhD in Public Administration, \\ Associate Professor of the \\ Department of Public \\ Administration and Law, \\ Dnipro Academy of Continuing \\ Education
}

У статті проаналізовано проблему предметної визначеності стратегічного планування освітньою сферою як складової теорії та практики науки державного управління. Підкреслено належність стратегічного планування освітою до механізмів державного управління та визначено його специфічні характеристики у иій якості. Обтрунтовано необхідність виходу за межі економічної детермінаціі діяльності у сфері стратегічного державного планування освітнього розвитку. Акцентовано значущість системно-модельного підходу до розуміння стратегічного планування в освіті. Установлено основні виміри стратегічного планування в освіті на інструментальному рівні.

Ключові слова: державне управління, стратегічне планування, освіта, механізм, моделювання.

В статье проанализирована проблема предметной определенности стратегического планирования образовательной сферой как составляющей теории и практики науки государственного управления. Подчеркнуто принадлежность стратегического планирования образованием к механизмам государственного управления и определены его специфические характеристики в этом качестве. Обоснована необходимость выхода за предель экономической детерминации деятельности в сфере стратегического государственного планирования образовательного развития. Акцентировано значимость системномодельного подхода к пониманию стратегического планирования в образовании. Установлены основные измерения стратегического планирования в образовании на инструментальном уровне.

Ключевые слова: государственное управление, стратегическое планирование, образование, механизм, моделирование.

The article analyzes the problem of subjective determination of strategic planning in the educational sphere as a component of the theory and practice of public administration science. The importance of strategic planning of education to the mechanisms of public administration is emphasized and its specific characteristics in this capacity are defined. The necessity of going beyond the economic determination of activities in the sphere of strategic state planning of educational development is substantiated. The importance of 
system-model approach to understanding of strategic planning in education is emphasized. The basic dimensions of strategic planning in education at the instrumental level are established.

Key words: public administration, strategic planning, education, mechanism, modeling.

Постановка проблеми. Стратегічне державне планування поєднує ефективність державного управління в освіті з успішністю інноваційних процесів в соціально-економічній сфері, виступає інструментом підпорядкування розвитку освіти цілям державного розвитку, інтересам зовнішніх суб’єктів, що забезпечує його пріоритетність у системі державного управління освітою в сучасних умовах. Стратегізація управління освітою, що здійснюється на основі застосування в державній освітній політиці стратегічного управління та планування як пріоритетних управлінських інструментів, виступає в якості ефективного засобу здійснення освітніх реформ в умовах кризових процесів. Стратегічне планування розглядається у контексті реформ галузі як один iз стратегічних напрямків усього процесу державотворення у нашій країні, як механізм ефективного здійснення модернізації у даній царині.

Аналіз останніх досліджень $i$ публікацій. Дослідження проблем стратегічного планування в сучасних умовах здійснюється у роботах О. Свмешкіної, Н. Пляскіної, І. Кочарян, Л. Приходченко та інших вітчизняних і зарубіжних авторів. Науковці достатньо широко аналізують потреби, особливості, напрями стратегічного планування у різноманітних сферах, включаючи освітню царину. Однак при цьому на периферії досліджень знаходиться визначення специфіки стратегічного планування як інструмента та механізму державного управління. Між тим найбільш важливим для розуміння державно-управлінської сутності стратегічного планування в освіті $є$ визначення його інструментальної належності як механізму державного управління.

Mema cmammi. Визначення особливостей стратегічного планування в освіті як механізму державного управління

Виклад основного матеріалу. У наявній літературі теоретикометодологічні засади державного управління описують як систему «способів організації та здійснення пізнавальної й практичної діяльності у сфері державного управління, що включає підсистему способів досліджень (понять, принципів, підходів, методів, норм, парадигм тощо) у сфері державного управління та підсистему способів (принципів, підходів, методів, методик, процедур, технологій тощо) державно-управлінської 
діяльності» [1, с. 346]. Виходячи з цього ми вважаємо, що найбільше значення для розуміння сутності стратегічного планування в освіті $є$ його характеристика як механізму державного управління.

У найбільш загальному вигляді механізм управління визначається як спосіб організації управлінської діяльності стосовно тих чи інших соціальних сфер чи процесів, у межах якого забезпечується поєднання методів управління його інструментарію та принципів на засадах ефективності досягнення запланованих результатів. У межах теорії управління є більш вузька інтерпретація даного феномену, і до механізмів управління відносяться структури, на основі яких здійснюється процес прийняття та реалізації управлінських рішень, а також і сам комплекс процедур ухвалення таких рішень [2].

У практичній діяльності органів державної влади конкретні механізми управління виступають у якості інструментів здійснення управлінських впливів на об'єкти з метою їх зміни. У цьому сенсі доцільно говорити і про методологічний вимір даного поняття, оскільки кожний механізм управління у практичній діяльності проявляється як метод чи сукупність методів впливу органів державної влади. Відповідно на рівні системи державного управління мова також має йти про механізм, як системну організацію управлінської діяльності держави, що включає комплекс організаційних складових та реалізацію управлінських функцій, як іiі організаційно-функціональну підсистему. Разом з тим слід говорити і про діяльнісний вимір механізму державного управління, тобто про процес його практичного здійснення.

Використання концепту механізму державного управління дає можливість аналізувати стратегічне планування в освіті як складний та складно структурований інструмент органів державної влади, що включає процес ціле покладання управлінської діяльності, аналіз об'єкта та методів управлінських впливів, визначення ресурсів розвитку та шляхів їх ефективного використання. По суті вона виступає як створена для реалізації державної освітньої політики управлінська система 3 власними нормативно-правовим забезпеченням, структурою, функціями, інструментарієм впливу, процесами та процедурами. Стратегічне планування поряд 3 інституціоналізацією, державною політикою, державно-управлінськими реформами $є$ системним механізмом державного управління, який реалізується через прості механізми (нормативно-правові, ресурсні, організаційні, функціональні). Його можна визначити як цілісну систему компонентів, на основі яких забезпечується 
вплив органів державної влади на освітню галузь 3 метою реалізації іiі державної стратегії розвитку, у більш широкому плані - як засоби, методи за допомогою яких органи державного управління освітою впливають на свій об’єкт для досягнення поставлених цілей.

Як механізм державного управління стратегічне планування відображає вплив різноманітних чинників на трансформації системи державної влади в країні та прагнення владних інститутів віднайти ефективні інструменти вирішення соціальних проблем. Як сучасний механізм державного управління освітою цей інструмент формується переважно на основі західних, уже добре апробованих методів стратегічного планування. Проте при цьому їх використання на сьогодні не дозволило вирішити завдання ефективного використання цього механізму для управління з боку органів державної влади розвитком галузі. Має місце постійне невиконання цілей державної освітньої політики і стратегії, відсутність цілісності та наступності стратегічного управління галуззю і достатньо обмежений вплив освітянських реформ на забезпечення завдань інноваційного розвитку країни. При цьому цілеспрямовані управлінські дії щодо організації та державного стимулювання інноваційного розвитку освітньої галузі дають досить неоднозначні результати. Стратегічні планові документи в освіті національного рівня (програми, концепції, доктрини) постійно змінюються достатньо хаотично, непослідовно і без щонайменших проявів їх виконання. Більше того, використання здавалося б добре обгрунтованих в інших країнах методів стратегічного планування дуже часто викликає посилення традиційних та появу нових освітніх проблем [3, с. 11].

На нашу думку, значною мірою подібний стан речей пояснюється саме недоліками науково-предметної визначеності стратегічного планування в освіті. Як різновид управлінської діяльності воно спрямоване на досягнення довгострокових цілей розвитку галузі в контексті інтересів суспільства і громадян. Цей вид діяльності має структурне оформлення у вигляді суб'єкт-об'єктних відносин, інструментарію, системи цілепокладання тощо, які визначаються зовнішніми для системи державного стратегічного планування структури умовами, що розробляються у межах певного наукового напряму. На сьогодні статус такої наукової основи дослідження та здійснення стратегічного планування в освіті має економічна теорія, саме на іiі основі у системі державного управління розробляється розуміння, опис і пояснення освітніх процесів.

Між тим концептуальний базис стратегічного планування уже 
вийшов далеко за межі економічної теорії. Підходи щодо стратегічного планування в системі державної влади здійснюються у межах теорії глобалізації, мережно-інформаційного суспільства, медіа-комунікативного простору, політичної діяльності тощо. Відповідно ми вважаємо, що концептуальною основою стратегічного планування мають стати засади та зміст інноваційних управлінських теорій, економічні ж методи мають відігравати роль лише технології реалізації загальної управлінської концепції державного стратегічного планування. Найбільш адекватною концепцією, що має застосовуватися до аналізу стратегічного планування як різновиду управлінської діяльності в освіті, має бути освітній менеджмент [4, с. 219]. При цьому стратегічне планування в освіті має бути інтерпретоване як формалізоване узгодження цілей та способів їх досягнення 3 боку органів державного управління галуззю та різних освітніх суб'єктів, що розраховане на реалізацію державної освітньої стратегії у середньостроковій перспективі. Цілі, проблемні питання суб'єкт-об'єктні управлінські відносини у державній освітній стратегії при цьому стають репрезентацією фактичного стану об'єкта управління та його соціокультурного оточення, що має відображення у певній системі емпіричних фактів, показників, індикаторів. Основним акцентом стратегічного управління стає розвиток освітньої інфраструктури, регулювання процесу використання ресурсів галузевого розвитку, формування освітнього простору як середовища життєдіяльності конкретних споживачів освітніх послуг.

Важливо також, що сучасні управлінські концепції (менеджеріальні, маркетингові, мережні) дають можливість, на відміну від теорій економічного детермінізму, аналізувати та враховувати процеси так званого «соціального стратегування», тобто різновекторні стохастичні соціальні процеси, за допомогою яких люди досягають своїх інтересів в освітній сфері. Більше того, саме такі процеси у межах синергетичноменеджеріальної методології розглядаються як передумова реалізація освітньої стратегії держави. Вони значною мірою відображені у просторових, особистісних, комунікаційних, локальних та інших характеристиках освітньої діяльності. Ігнорування таких процесів і робить непридатною для стратегічного планування в освіті методологію традиційних економічних підходів, пов'язаних 3 акцентуванням управління ресурсами чи безпосереднього директивного впливу на об'єкти управління. Ми згодні 3 дослідниками, які вважають, що «внаслідок поширення методології економічної науки на не властиву їй предметну 
область - освіту - відбувається спотворення в описі і поясненні соціальної реальності. Через це, стратегічне планування як вид управлінської діяльності є неадекватним об'єкту» [5, с. 24]. Розуміння стратегічного планування в освіті у межах економічних концептуальних засад робить державну галузеву стратегію розвитку неефективною, статичною, відірваною від соціальних та освітніх потреб.

На нашу думку, адекватна управлінська теорія полягає у застосуванні інноваційних управлінських парадигм, які розглядають стратегічне планування як механізм ініціювання та керування освітніми змінами, що має суб'єктну природу. У центрі такого стратегічного планування знаходиться не вплив на соціальну інфраструктуру освітньої галузі та іiі ресурси, а інституційне управління освітніми процесами на основі системного ціннісно-нормативного регулювання. Основною характеристикою такого стратегічного планування $є$ його здійснення у відповідності з потребами та реальною діяльністю усіх освітніх суб'єктів, 3 орієнтацією на їх зацікавленість у здійсненні державної стратегії галузевого розвитку. Відповідно таке планування потребує значно ширшого інформаційного забезпечення, ніж традиційне, насамперед стосовно потреб та мотивів діяльності освітніх суб'єктів.

Виходячи $з$ такого розуміння сучасних підходів щодо дослідження та здійснення стратегічного планування в освітній галузі, на перше місце висувається дослідницький інструментарій, пов'язаний 3 процесами моделювання та проєктування освітніх процесів. Це найбільш адекватний науковий інструментарій для обгрунтування та застосування державної стратегії освітнього розвитку, а тому сучасні підходи передбачають використання модельного апарату стратегічного планування. На сьогодні моделювання широко використовується у діяльності органів державної влади, насамперед для оптимізації розвитку освіти та іiі складових [6]. Аналіз практичної управлінської діяльності та наукових досліджень дозволяє зробити висновок про найбільшу значущість модельнопроєктного інструментарію у процесі програмно-цільового галузевого планування, ініціювання та реалізації стратегічних освітніх проектів різного рівня, формування мережевих освітніх систем, створення сучасних систем підготовки та прийняття управлінських рішень у процесі реалізації стратегічних освітніх програм. Особливо великий потенціал має тенденція до моделювання не лише освітнього розвитку, а й процесу прийняття рішень щодо стратегічного управління ним та можливих сценаріїв результатів такого управління. 
Моделювання доцільно використовувати для визначення специфіки стратегічного планування в освіті на різних рівнях, для опрацювання цілепокладальної основи освітньої стратегії, для оптимального опису результатів реалізації галузевої стратегії розвитку та інших аспектів. Специфіка використання модельного підходу головним чином визначається способах відображення у модельному інструментарії інституційного контексту освітньої діяльності, при цьому зовнішні чинники формулюються у вигляді нормативних та цільових іï основ; а внутрішні безпосередньо стосуються моделі управлінської діяльності. На нашу думку, потрібно виділити кілька концептуальних рівнів моделювання процесу стратегічного планування освітнього розвитку [7].

По-перше, це освітній вимір моделі соціально-економічного розвитку країни загалом. Тут у якості методології слід використовувати мета модельні (метапарадигмальні) синтези та міждисциплінарний підхід, концепції стратегічного прогнозування на національному рівні, інтегровано-програмний підхід 3 визначенням місця освітніх проєктів у загальному процесі модернізації країни, сценарну методологію для визначення оптимального інноваційного курсу галузі у процесі становлення інноваційної моделі розвитку. Що стосується модельного інструментарію, то потрібно застосовувати синтез соціально-економічних, управлінських та галузевих моделей у межах модельно-програмного комплексу. Це вищий рівень розробки стратегії, і його результатом має бути концепція трансформації галузі на інноваційних засадах у контексті завдань соціально-економічної модернізації. Вказана концепція визначає цілі та завдання освітніх інновацій, конкретні механізми їх здійснення у стратегічній перспективі, прогнозно-сценарні моделі 3 врахуванням чинників, ресурсів, ризиків реалізації стратегії, і як завершення - вихід на формулювання основних положень державної стратегії освітнього розвитку і проєктів, у межах яких вона має реалізовуватися.

По-друге, це системна модель проєктування освітніх змін на урядовому рівні, яка i $є$ конкретизацією стратегічних освітніх програм. При цьому найбільш ефективною методологією слід вважати інтегрованопроєктивний підхід, який дозволяє у межах єдиної стратегії освітнього розвитку об'єднати інноваційні проєкти різної спрямованості з розумінням їх обумовленості глобальними трендами розвитку країни. Така системногалузева модель грунтується на використанні програмно-цільового планування та прогнозування, визначенні механізмів забезпечення інноваційних стратегічних освітніх проєктів 3 боку органів державної 
влади, використанні інструментарію конкретно-ситуаційного моделювання впливу освітніх проєктів на процес модернізації. Управління освітніми проєктами має здійснюватися на основі комплексного моделювання управлінських аспектів інновацій та їх впливу на об’єкт управління. Усе це передбачає використання різноманітного модельно-аналітичного інструментарію у вигляді когнітивного моделювання як поєднання процесу стратегічного проєктування і процесу управління реалізацією проєктів; створення інтегративних моделей взаємодії розвитку освітньої системи та реалізації стратегічних проєктів з конкретними показниками ресурсного забезпечення. Результатом моделювання має бути детально розроблена державна стратегія розвитку освіти та іiі конкретизація у комплексних освітніх проектах і програмах з чітким планом їх поетапного здійснення, фінансуванням, організаційною підтримкою i матричною структурою управління освітніми проєктами, нормативним забезпеченням, прогнозними орієнтирами результатів і впливу на розвиток галузі та країни.

У цілому стратегія розвитку освіти представляється як системний інноваційний проєкт модернізації галузі, що реалізується комплексом стратегічних освітніх проєктів і для своєї реалізації потребує формування структури, що здійснює управління цим проєктом (управління стратегічним розвитком освіти). Вказане управління здійснюється у процесі застосування різноманітних методологій проєктивного управління (модельного, мультипроективного, модельно-сценарного тощо) i приводить до формування цілісної системи державного управління інноваційною стратегією розвитку галузі, що функціонує на базі модельного комплексу стратегічного планування та управління. Організаційною формою такого управління i планування може бути спеціалізований центр у межах галузевого міністерства, який забезпечує ресурсами освітні проєкти, дію механізмів державної підтримки цих проєктів і узгодження діяльності усіх учасників стратегічних програм.

Моделювання має також регіональний та муніципальний вимір, де застосовуються подібні ж модельні підходи, формуються відповідні центри стратегічного управління та планування. Проте на цьому рівні вони мають загально-територіальний характер, стратегії розвитку освіти вписуються у стратегії регіонального чи муніципального розвитку для їх здійснення можливе створення координаційних груп у межах органів державної влади та самоврядування [8, с. 168]. Теорія модельного підходу тут має певну специфіку у царині бюджетування регіональних освітніх 
проєктів, оскільки останні мають бути узгоджені 3 конкретними регіональними пріоритетами та системами управління в умовах децентралізації. Саме на регіональному рівні відкриваються можливості використання в стратегічному плануванні та управлінні потенціалу соціального партнерства, а також більш активно має здійснюватися моделювання мотивації суб'єктів освітнього розвитку до інноваційних змін і їх кадрового забезпечення (особливо слід звернути увагу на цільову підготовку освітніх менеджерів).

Загалом основна перевага модельно-проектного підходу державного планування та управління в освітній галузі полягає у забезпеченні організаційних механізмів реалізації державної освітньої стратегії на всіх рівнях за рахунок їі переведення у конкретні інноваційні освітні проєкти 3 відповідною управлінською інфраструктурою ресурсним забезпеченням, технологічним процесом досягнення результату. Стратегічне планування набуває конкретики та обгрунтованості, оскільки модельний інструментарій проєктного управління включає імітаційні та мережеві прогнозні моделі, що дає можливість обгрунтовано визначитися 3 ефективністю тих чи інших форм i механізмів державної підтримки освітніх проектів. У межах модельного підходу враховуються особливості розгортання таких проєктів у конкретному соціокультурному середовищі і різноманітні альтернативи їх реалізації, діяльності освітніх суб'єктів, впливу на навколишнє середовище і конкретні групи населення тощо.

Висновки $i$ перспективи подальших досліджень. Таким чином, особливостями стратегічного планування як механізму державного управління освітою $\epsilon$ його концептуальне обгрунтування на основі інноваційних управлінських парадигм, використання управлінського інструментарію, включення до системи моделювання розвитку на основі поєднання галузевого та державно-управлінського аспектів. Стратегічне планування слід віднести до базових механізмів державного управління 3 відповідною структуризацією стосовно рівнів управлінської діяльності. Найбільш важливою проблемою при цьому є поєднання стратегічного планування на різних рівнях державного управління та місцевого самоврядування, що має стати предметом подальших досліджень.

\section{Лimepamypa:}

1. Методологія державного управління: слов.- довід. / уклад.: В. Д. Бакуменко, С. В. Бутівщенко, Д. О. Безносенко, О. М. Руденко та ін. / за заг. ред. В. І. Лугового, В. М. Князєва. К.: Вид-во НАДУ, 2004. 416 с. 
2. Усаченко О.О. Розвиток системи базових механізмів державного управління: автореф. дис. ... канд. наук з держ. упр.: 25.00.02. Міжрегіон. Акад. упр. персоналом. Київ, 2018. 20 с.

3. Свмєшкіна О. Л. Теоретико-методологічні засади модернізації системи державного стратегічного планування в Україні: монографія. Київ: УкрСІЧ, 2017. 394 с.

4. Братаніч Б. В. Освіта як об'єкт управління в інформаційному суспільстві. Трансформація управління вітчизняною освітою на принципах освітнього менеджменту. Мат. Всеукраїнської науково-практичної конференції. 09 червня 2016 р. Дніпро: ТОВ «Інновація», 2016. С. 218-221.

5. Пляскина Н. И., Харитонова В.Н. Трансформация методологических подходов и модельного аппарата системы стратегического планирования и управления. Мир экономики и управления. 2017. T. 17. № 4. C. 22-38.

6. Кочарян I. С. Управління вищою освітою: методи, моделі та інформаційні технології: монографія. Київ: КНЕУ, 2015. 233 с.

7. Хитько М. М. Концептуальні засади досліджень стратегічного планування у державному управлінні освітньою галуззю. Менеджер. Вісник Донецького державного університету управління. Серія «Державне управління». 2018, № 3 (80). С. 61-68.

8. Стратегічне планування в системі публічної влади / за заг. ред. Л. Л. Приходченко. Нац. акад. держ. упр. при Президентові України, Одес. регіон. ін-т держ. упр. Одеса: ОРІДУ НАДУ, 2015. 195 с.

\section{References:}

1. Metodologhija derzhavnogho upravlinnja: slov.- dovid. / uklad.: V. D. Bakumenko, S. V. Butivshhenko, D. O. Beznosenko, O. M. Rudenko ta in. / za zagh. red. V. I. Lughovogho, V. M. Knjazjeva. K.: Vyd-vo NADU, 2004. $416 \mathrm{~s}$.

2. Usachenko O. O. Rozvytok systemy bazovykh mekhanizmiv derzhavnogho upravlinnja: avtoref. dys. ... kand. nauk z derzh. upr.: 25.00.02. Mizhreghion. Akad. upr. personalom. Kyjiv, 2018. 20 s.

3. Jevmjeshkina O. L. Teoretyko-metodologhichni zasady modernizaciji systemy derzhavnogho strateghichnogho planuvannja v Ukrajini: monoghrafija. Kyjiv: UkrSICh, 2017. 394 s.

4. Bratanich B. V. Osvita jak ob'jekt upravlinnja v informacijnomu suspiljstvi. Transformacija upravlinnja vitchyznjanoju osvitoju na pryncypakh osvitnjogho menedzhmentu. Mat. Vseukrajinsjkoji naukovo-praktychnoji 
konferenciji. 09 chervnja 2016 r. Dnipro: TOV «Innovacija», 2016. S. 218-221.

5. Plyaskina N. I., Kharitonova V. N. Transformatsiya metodologicheskikh podkhodov i model'nogo apparata sistemy strategicheskogo planirovaniya i upravleniya. Mir ekonomiki i upravleniya. 2017. T. 17. № 4. S. $22-38$.

6. Kocharjan I. S. Upravlinnja vyshhoju osvitoju: metody, modeli ta informacijni tekhnologhiji: monoghrafija. Kyjiv: KNEU, 2015. 233 s.

7. Khytjko M. M. Konceptualjni zasady doslidzhenj strateghichnogho planuvannja u derzhavnomu upravlinni osvitnjoju ghaluzzju. Menedzher. Visnyk Donecjkogho derzhavnogho universytetu upravlinnja. Serija «Derzhavne upravlinnja». 2018, \# 3 (80). S. 61-68.

8. Strateghichne planuvannja $\mathrm{v}$ systemi publichnoji vlady / L. L. Prykhodchenko ta in. / za zagh. red. L. L. Prykhodchenko. Nac. akad. derzh. upr. pry Prezydentovi Ukrajiny, Odes. reghion. in-t derzh. upr. Odesa: ORIDU NADU, 2015. $195 \mathrm{~s}$.

The article analyzes the problem of subjective determination of strategic planning in the educational sphere as a component of the theory and practice of public administration science. The use of the concept of the mechanism of public administration makes it possible to analyze the strategic planning in education as a complex and complex structured tool of public authorities, which includes the process of entrusting management activities, analyzing the object and methods of administrative influence, identifying development resources and ways of their effective use. Approaches to strategic planning in the system of state power are carried out within the framework of the theory of globalization, network-information society, media-communication space, political activity, etc. The conceptual basis of strategic planning should be the foundations and content of innovative management theories, and economic methods should play the role of only technology to implement the general management concept of state strategic planning. Simulation should be used to determine the specificity of strategic planning in education at different levels, to elaborate the overall basis of the educational strategy, to optimally describe the results of the implementation of the sectoral development strategy and other aspects. The specificity of using the model approach is mainly determined by the ways in which the institutional context of the educational activity is reflected in the model toolkit, with the external factors being formulated in the form of normative and target bases; and internal ones are directly related to the 
management model. The main advantage of the model-project approach of state planning and management in the educational sector is to provide organizational mechanisms for the implementation of the state educational strategy at all levels by translating it into specific innovative educational projects with appropriate management infrastructure resource provision, technological process of achieving results. Features of strategic planning as a mechanism of public administration of education are its conceptual justification on the basis of innovative management paradigms, use of management tools, inclusion in the system of development modeling based on a combination of sectoral and stateadministrative aspects. Strategic planning should be attributed to the basic mechanisms of public administration with appropriate structuring in terms of levels of management. The most important problem is the combination of strategic planning at different levels of government and local self-government. 